\title{
Turning the herding lifestyle into a learning opportunity: Experiences from Lesotho
}

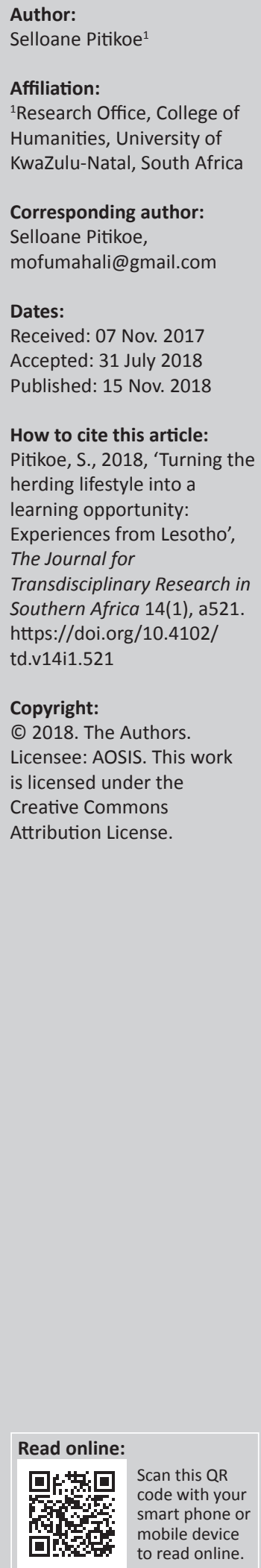

\begin{abstract}
This article addresses the complex ways through which Basotho herders acquired indigenous knowledge (IK) through their herding practice. For centuries, Basotho males have practiced livestock herding as an alternative form of employment while also perceiving it as a quicker way of accruing personal livestock wealth. This socio-economic discourse has further rendered male Basotho at a disadvantage in terms of education access because of the semi-nomadic nature of herding and the inaccessibility of the herding topography. The article draws on data collected using semi-structured interviews, as well as the photovoice and the transect walk techniques, conducted with a group of 30 male Basotho herders aged between 18 and 45 years, representative of the highlands, foothills and the lowlands of Lesotho. This article aims to address two research objectives. Firstly, it interrogates how Basotho herders learn through herding. Secondly, it explores how the empirical findings harvested from this article can inform Lesotho's non-formal education policy and practice reform. It was discovered that herding comprises a wealth of undocumented IK, which comes in two forms: local science and local practice knowledge. Finally, the article suggests ways that Lesotho's mainstream education may consider reforming the current education policy and practice. It is anticipated that this article will significantly contribute to the IK scholarship elsewhere in the world on issues pertaining to livestock herding and herders' access to education.
\end{abstract}

\section{Introduction and background}

This article addresses the complex ways through which Basotho herders acquire indigenous knowledge (IK) through their herding practice. Evidence reveals that Basotho perceive herding as a cultural rite of passage that transforms males into 'real Basotho men', who are considered responsible and resilient enough to withstand the shocks and stresses of life (Johnson 2016). While in the past, herding was a binding practice for all Basotho males, of lately the popularity of herding is seen and felt in the rural areas of Lesotho while the urban-based males enrol in formal education programmes (Pitikoe 2017). This is because animal husbandry forms the main livelihood source for rural communities as opposed to the formal labour market opportunities that the urban-based citizenry has. Pitikoe and Preece (2016) agree with the Ministry of Education and Training (MoET 2005) that most Basotho males assume the herding role at a very tender age from as young as 3 years, when they are legally expected to begin their pre-primary education. For Basotho males, livestock herding satisfies both the social and economic needs. For instance, some males join the herding fraternity as an alternative employment where the proceeds become a resource for poverty alleviation.

In Lesotho and elsewhere in the world, males are culturally socialised as providers for their families; hence they become the first-line resort to look up to when families become financially incapacitated (Pitikoe \& Preece 2016). Pitikoe (2016), Ratau (1988), Morojele (2009) and Makoa and Zwilling (2005) are in agreement that the age at which herding begins and the sociocultural perception of herding coupled with poverty bear heavily on male Basotho's access to education, such that for them herding is an important remedy for addressing immediate needs while the benefits of education are enjoyed at a later stage in life. Nonetheless, evidence reveals that herding generates a wealth of undocumented herding IK that Basotho herders use in order to cope with their daily herding routine. This knowledge is an informal product of social learning and interaction with their peers, the environment and the elders. Subsequently, the engagement that the herders have with both the conceptual and theoretical abstractions of IK construction indicates the potential contribution that IK can make in developing the curriculum of all forms of pedagogical teaching and learning in Lesotho.

The small country of Lesotho was under British rule from 1868 until it finally became independent in 1966 (Gill 1993). However, colonial development left among others a very small rugged portion 
of land approximated at $30355 \mathrm{~km}^{2}$ (11 000 square miles) (Ministry of Health and Social Welfare 2009), situated at an average elevation of $1800 \mathrm{~m}$, where $80 \%$ of the total area is covered with mountains that make a suitable habitat for livestock farming (MoHSW 2009). There are four main geographic regions in Lesotho - the highlands, foothills, the Senqu River Valley and the lowlands. Johnson (2016:1) argues that the inaccessible topography coupled with the extreme highland weather conditions remain a challenge for herders' access to the service providers as much as it does if the reverse is the case to providers, who are unable to reach Basotho herders in order to provide them with social services such as health and education. Johnson further posits that in extreme cases, this inaccessibility results in 'at least 5-20 herdboys [who] die from being snow-trapped in the mountains, sometimes alone'.

Located within her only neighbour, South Africa, places Lesotho's economy at the mercy of South Africa in terms of import and exports. As a result, the sociocultural and political as well as economic changes that affect South Africa's economy reverberate into Lesotho (Government of Lesotho [GOL] 2015). Lesotho's male-female ratio is 1.03 (97 males to 100 females) (GOL 2015). An estimated $70 \%$ out of a total population of 2243676 Basotho reside in the impoverished rural areas of Lesotho (ibid). The Government of Lesotho (2015) further posits that the most poverty-stricken sectors of the population are the elderly and the youth aged between 15 and 35 years old.

Pitikoe and Preece (2016; 2017) echo (Pitikoe \& Morojele 2017) that the patriarchal nature of Basotho reinforces gendered social roles and responsibilities, where males are associated with leadership roles and the responsibility to protect and provide for their families, in the process placing livestock herding in the male domain. Basotho associate herding with wealth and masculinity identity construction that every male Mosotho strives for (Pitikoe 2017). Baloyi (2014), Choabi (2016); Letsosa and Semenya (2011); Maloka (1998), Matšela (1979) and Opong (1997; 2004) all agree that livestock wealth is central to cultural rituals and feasts such as funerals, appeasing the ancestors and payment of lobola dowry. If a family experiences misfortunes or bad luck, the general belief is either that it is a manifestation of evil forces or the unhappiness of the ancestors. In such cases, a divine healer is approached to seek guidance on how to bring back luck. Matšela (1979) agrees with Opong (1997; 2004) that upon completion of a divine healing, the divine healer gets paid with a live cow.

Equally important, Pitikoe (2016) agrees with Ratau (1988) in the recognition of 'male identity construction' through livestock wealth. Further important is the number and variety of livestock owned by the family head (the older male who is in charge of the family). Just as important is the herding experience that a male Mosotho has - his ability to withstand the adversity of herding denotes toughness that was constructed through the herding rite of passage. Herding is also perceived as a potentially quicker way of accumulating personal livestock wealth, in that those who herd animals (for either their families or their employers) are remunerated with livestock as an induction process into their future role as livestock owners. Such herders would, in turn, give their accrued livestock a personalised and distinct ear mark (Pitikoe \& Morojele 2017).

Lefoka (2007), Johnson (2016), Morojele (2009) and Nthunya (1996) studied herding in Lesotho, where they identify herding as a convenient employment opportunity for those males who did not have an opportunity to participate in any form of education or had to drop out of the system before completion. Studies on herding (Makoa \& Zwilling 2005, Nthunya 1996, Ratau 1988, Morojele 2009 and Opong 1997) all concur that such herders usually seek employment from the local wealthy livestock owners for a minimum social contract (verbal or written) of 12 months, upon completion of which they are remunerated with live animals, whose number and type is determined by the employer such that it equates to the current market value for a live cow. It can therefore be argued that the high influx of rural-based Basotho males into the herding fraternity may be driven by the need to secure personal livestock wealth so that they can befit from the public identity status of being 'real Basotho men'.

\section{The problem statement}

In Lesotho, the education system mainly comprises formal and non-formal education (NFE) under the guardianship of the MoET (2005). While the former receives full financial support from the government, the latter is considered to be a second class provision that is meant for those learners who do not qualify for enrolment in institutions of higher learning. Therefore, it does not enjoy as much government will and support (Pitikoe \& Preece 2016). It is also noteworthy that Lesotho's policy documents on NFE and Open Distance Learning are still in their draft forms, a situation that makes it even harder for NFE programmes to be perceived as worthy of support (MoET 2005). While formal education is doing well with regards to financial and resource-based support, the provision also lags behind in the enforcement of education acquisition for all Basotho.

Lesotho has responded to the international policy environment urging poverty eradication and provision of universal and compulsory education (Pitikoe 2016). To that effect, education in Lesotho is indeed compulsory but not binding. This is because the Education Act of 2010, whose mandate is to make education binding and accessible to all children of school going age (6 years and above), has delayed its launch. This delay coupled with the current political instability leave a window of opportunity for parents and livestock owners to choose whether to take their children to formal schooling or not. While NFE remains in the periphery in terms of support, its flexible nature and limited confinement within the traditional classroom makes it a better suited provision for the herders (Pitikoe \& Preece 2016; 2017). 
Currently, NFE in Lesotho is offered by non-governmental organisations (NGOs), who are donor-funded and donordriven (Pitikoe 2017). Therefore, the curriculum is donordriven and has not been customised to meet the local education needs of Basotho.

Indigenous knowledge has been in existence in Africa and elsewhere in the world for time immemorial. It has always been recognised for its holistic nature (noncompartmentalised), where teaching and learning are incorporated into the daily routine (Magni 2016). However, the oral nature of IK implies a wealth of undocumented IK and its potential contribution to teaching and learning practice. Following the colonial introduction of conventional education, because of the impression that education was a foreign concept in Lesotho, IK has been relegated to a lower standard to that of formal education (Pitikoe \& Morojele 2017). This gap misinforms decision-making processes on how to tap on existing IK in order to decolonise Lesotho's current education provision.

Lesotho introduced Free Primary Education (FPE) in 2000 with the intension to accommodate all school-aged out-ofschool Basotho children to access education (MoET 2005). While FPE significantly increased Lesotho's literacy statistics, the gender disparity in education access still remains. Seemingly, the introduction of FPE was premature, and hence it was unable to provide sufficient infrastructural and human capital to drive the process forward. Therefore, both adults' and children's classes were combined. The classroom overcrowding, resulted in less time allocated for individual face-to-face consultations, in the process demotivating adult learners who had high hopes for their future; hence, there was high learner dropout to join the herding fraternity while leaving behind the girls to continue with formal education (MoET 2001a; 2001b). The high male dropout rate may be attributable to some unknown attractive features of herding that are lacking in the formal provision but known only to the herders, in the process making herding more appealing to their education needs. Ratau (1988), Nthunya (1996) and Makoa and Zwilling (2005) agree on the significant contribution that herding makes to masculine identity construction. However, what is lacking in the literature is how herders learn while herding, the gap that this article seeks to address. Additionally, the literature does not provide a detailed perspective from the herders on how Lesotho can integrate IK into the formal provision in such a way that the mainstream provision can be more appealing to their educational needs; this will be explored further in this article.

\section{Theoretical framework}

The findings in this article are filtered through the IK theory. Recent studies on IK (Frąckowiak 2017; Johnson 2016; Magni 2016; Ngozwana 2014; Nyiraruhimbi 2012; Osborne, Cutter \& Ullah 2015; Pitikoe \& Morojele 2017) all refer to IK as localised knowledge that is generated and owned by the local communities. However, in this article I borrow the definition of IK by Odora Hoppers (2017a), who refers to IK as:

knowledge that is held and used by a people who identify themselves as indigenous to a place based on a combination of cultural distinctiveness and prior territorial occupancy relative to a more recently arrived population with its own distinct and subsequently dominant culture. (p. 4)

This definition views IK as deeply rooted within the cultural homogeneity of the indigenous community as a guide to their fundamental ways of life. Recent studies (Johnson 2016; Ngozwana 2014) all concur that IK is dynamic and orally passed on from older generations to the younger ones. Nyiraruhimbi (2012), on the other hand, identifies three types of IK as follows. Firstly, IK is a local science: deliberate knowledge that has been generated over time using the local technologies - for instance using traditional herbs, also cited in Moteetee and Van Wyk (2011). Secondly, IK is the local memory: a product of socialisation and memorisation of knowledge, such as in reciting poems. The third category is that of local practice, which refers to unconsciously constructed knowledge using the trial and error technique. One example would be the decoration of the herders' grey blanket. The global outcry for member states to appraise the significant role that IK can play in development has been underscored under Goal 4 of the Sustainable Development Goals (Osborne et al. 2015).

While most scholars agree that one of the limitations of IK is its oral nature, which limits its replicability beyond the local context, World Bank (1998) identifies six steps through which developing member states can share IK as follows:

- Recognition and identification: which involves discrete mixing of local technologies or cultural values.

- Validation: which emphasises the need to assess the significance and relevance of IK in relation to its reliability, functionality, effectiveness and transferability in problemsolving.

- Recording and documentation: While this still remains a current challenge, the World Bank advocates for a strategic move that uses modern technology to capture and preserve existing IK such as tapes, audio clips, drawings, photography, as a few of the resources to tap into.

- Storage in retrievable repositories: Under this step, the emphasis is exploring other storage means that move beyond the traditional confinement into print and media-based digital storage technologies such as films, videos, blogs, books and gene banks as some of the examples.

- Transfer: This step goes beyond a mere knowledge conveyance to application of the new knowledge in a small, controlled new environment such as pilot studies in order to test its efficacy.

- Dissemination: for a wider consumption that benefits developmental initiatives through the impact of the ripple effect of knowledge on such knowledge transfer. 
Indigenous knowledge scholars underscore the importance of the local communities' voice being heard in developing initiatives that aim to change their lives for the better (Preece 2013). Similarly, Webb (2017) underscores the need for an African research rebirth for an inclusive knowledge production. Moreover, Odora Hoppers (2017b) suggests a need for new strategies that will disenfranchise the epistemological education into an encompassing African human development initiative that builds on the existing knowledge. These arguments place community participation on a pedestal in order to effectively promote change at community level.

In this article, IK becomes a theoretical frame of reference through which the findings of this article will be filtered. The author also explores ways which Lesotho can use the findings to inform the education policy and practice reform. This understanding will further inform Lesotho's NFE provision and practice in order to address the herders' learning and educational needs. Studies from Lesotho (Lefoka 2007, Pitikoe 2016 and Morojele 2009) all agree that herding is semi-nomadic and mostly practised in the hard-to-reach areas of Lesotho, in the interim making social services such as education and health inaccessible (Pitikoe 2016). Nonetheless, more rural-based Basotho males continue to move into the herding community seeking employment opportunities for poverty alleviation (Lefoka 2007). While education is a basic right for every human being, seemingly, poverty is one of the impediments to education access (UNDP 2012). This article seeks to address two research objectives. Firstly, it interrogates Basotho herders' ways of learning IK through herding. Secondly, the article explores ways through which the empirical findings harvested from this article can inform Lesotho's NFE policy and reform process. In order to address these two objectives, the outline of the article is as follows. In the following sections I present the research design followed by the findings and discussions. Finally, I will present the conclusion section.

\section{Research design: Context, methodology and data generation Design}

This qualitative study used the interpretivist paradigm (Chilisa \& Preece 2005) and the narrative life history approach in order to generate the herders' data on IK constructions. The article aims to address two objectives: firstly, it interrogates Basotho herders' ways of learning through herding. Secondly, it explores how the empirical findings can inform Lesotho's NFE policy reform.

\section{Context}

The study was conducted in the highlands, lowlands and foothills of Lesotho. The highlands cover $80 \%$ of the total area of Lesotho, and the ruggedness of this geographic zone makes it highly suitable for animal husbandry in the form of cattle post herding because of the fertile pasture lands. The lowlands, on the other hand, occupy only $10 \%$ of the total area and they are considered arable and suitable for crop husbandry, and the foothills and the Senqu River Valley share the remaining $10 \%$ out of the total area (MoHSW 2009). Communities living in the foothills combine crop and animal husbandry. The study participants represented the following communities: in the highlands, Linakeng in Thaba Tseka District; Linakaneng in Mokhotlong District; Khalong la Baroa in Maseru District; Malimong in Berea District; 'Melikane in Qacha's Nek District and 'Matšooana in Thaba Tseka District. The foothills communities comprised Makhaleng in Mohale's Hoek District; Matelile in Mafeteng District and Nazareth in Maseru District. The lowlands group came from Ha Tsolo in Maseru District; Ha Motloheloa in Maseru District and Selakhapane in Berea District.

\section{Population and sampling}

In order to avoid selection bias, the sampling process excluded the participation of the cattle post owners, as the herders' employers and the community leaders by virtue of their leadership and potential vested interest in the herding practice. Instead, I firstly compared the characteristics of the understudied phenomenon in this case, being Basotho herders, with my research objectives as highlighted in Rakotsoane and Rakotsoane (2007). Secondly, I based my selection on the cost-effectiveness, accessibility and manageable procedural demands as my key prerequisites for a good project sample as cited in Ekaju (2011). Therefore, in this study a theoretical sample was adopted instead of a representative one. Out of an estimated total of 22000 (Matope 2011) Basotho herders, the study snowballed into 30 herders aged between 18 and 45 years. This sampling was enabled through the partnership that I had already solicited with Monna ka Khomo Herdboys Association of Lesotho (gatekeepers on issues pertaining to the herders), which then came in handy in the identification of the key informants who had membership in the association. The involvement of the key informants helped me to further identify and locate other herders with similar characteristics. The eligibility criteria for participation included the following:

- age range of between 18 and 45

- male adults

- cattle post life background (for both current and former herders)

- prior participation in formal and NFE intended for the herders.

Initially, I had intended to distribute the number of the participants equally across the three geographical zones. However, given the observations made during the study, some alterations were effected with regard to the numbers. For instance, while there were more cattle posts in the highlands, none existed in the lowlands, which called for a need to increase the highland numbers in order to compensate for the lowland figures. Also, the richness of the data that came from the highlands herders justified the increase in numbers, as more time was spent in the highlands, where 
herders seemed more open and willing for their voices to be heard amidst the remoteness of their location. In the end, the representation of the participants across the three regions was as follows: I had 13 highlands participants; 10 foothills participants and 8 lowlands participants.

\section{Data collection}

Chilisa and Preece (2005) assert that the findings of good research come from individualised rather than generalised responses. This notion informed the choice and use of interviews, which are categorised among the central data collection methods as stated in Arthur et al. (2012). Arthur et al. caution that in choosing this method, the researcher has to be familiar with the advantages and disadvantages of the tool beforehand. I selected the interview method because it enabled me to ask probing questions of the respondents, with the opportunity to ask for clarification or elaboration if required. The study employed semi-structured interviews and photovoice as well as transect walks as the data collection techniques. Before embarking on the data collection process I had to carefully consider some of the potential barriers that may have hampered the process. Firstly, I took into consideration the tight schedule of events for my $\mathrm{PhD}$ study and carefully maximised the use of the limited financial resources within the tight $\mathrm{PhD}$ programme. Given the adversity of Lesotho's climate, particularly the highlands winter where heavy snowfalls are not foreign, care was taken to collect data in the highlands against the seasonal shift. The interviews were administered by the researcher onsite while the herders were busy with their daily herding routing. This approach enabled the researcher to observe the herding lifestyle while also picking up some of the nonverbal herding communication. Most importantly, it enabled me to have first-hand experience of entering a maledominated cattle post area, which is renowned for safety and security threats for females.

Williams and Metz (2014) opine that the photovoice technique gives the voiceless members of the society an opportunity to voice issues of concern to their lives. In my study I had initially planned to purchase at least 30 disposable cameras that were to be left with each herder so that they could take pictures of things that mattered most in their herding life at their own time. It was also assumed that time would be set aside where the herders would present and elaborate more on the pictures that they took. However, given the budgetary constraints, the initial plan did not see the light of the day. Instead, I used both my Blackberry phone and my digital camera to take pictures. Then I uploaded the pictures to my laptop and saved them using different folders that bore the herders' nicknames. A date was set where the herders described the importance of the photos in their personal as well as herding lives. The transect walk empowers local communities with context-specific problem-solving skills (Shar, Kambou \& Monahan 1999), while also opening an opportunity for the researcher to probe further on issues that may have emerged during the interview. In this study the transect walks were conducted in the company of another herder who was identified as knowledgeable about the surrounding environment, given the length of time that he had served as a herder based in that particular location. During the tour, I sketched the route in the field journal and also did an audio recording of the conversation that took place during the tour. At the end of the tour we gathered the herders together to discuss the findings of the tour and also presented the schematic map to the herders for them to verify and fill in the missing information.

These data collection tools and the participatory approach that the study employed significantly contributed in the establishment of a wealth of resourceful herding IK and the holistic manner through which herders learned from their herding practice. The onsite data collection not only established the complexities of the herding context but also examined first-hand experiences of the underlying life stories of Basotho herders. The language used for collecting data was Sesotho (language of Basotho) in order to allow the participants to express themselves fully in the language that they were comfortable with while at the same time maintaining research integrity, trust and rapport.

In her argument, Odora Hoppers (2017b) points to the need for research methods to promote ownership of the findings by the beneficiaries. The article used semi-structured interviews in both the participatory data collection techniques of photovoice and the transect walk. Photovoice enabled the herders to express and reflect their unknown realities into the public arena to facilitate policy change (Williams \& Metz 2014). While the transect walk empowered the local communities such as Basotho herders with context-specific problem-solving skills (Shar et al. 1999) it also helped the researcher to probe the herders' perspective on the historical background of the local resources, how the resources were used and distributed and how they foresaw the future of their land use. In this study three transect walks were conducted - one per geographical region. The different geographical areas presented variations in the lifestyles of the local communities who resided in these three geographical zones. For instance, the lowlands evidenced the communities' engagement in crop farming while the foothills and the highlands were primarily animal husbandry with minimal crop farming; hence the cattle posts were identified in larger numbers. Additionally, the highlands and foothills had a massive presence of natural resources for pastureland, the feature that was lacking in the lowlands.

\section{Data analysis}

The collected data were inductively analysed by translations from Sesotho into English, carefully using the audio recorder to listen to the taped conversations and translating them verbatim. This process helped to identify similar patterns and themes on ways in which Basotho herders learned through herding. The transcripts were also reread in order for the researcher to be familiar with the data and any possible emergent subthemes. The author revisited the 
objectives in order to link them to the collected data, the literature discussions and the interpretivist nature of the study as well as the theoretical lens of the study. In order to understand how Basotho herders learned, the study used the following five questions:

- What is your highest level of education?

- What do you like or dislike about your herding job?

- What learning have you acquired through herding?

- How did you acquire that learning?

- How is that knowledge benefitting you in your herding practice?

\section{Ethical consideration}

The study observed all the necessary ethical considerations during and after the study. These included seeking ethical clearance from the University of KwaZulu-Natal's research office. Additionally, the following stakeholders were contacted to seek their consent for the study. The Ministry of Education and Training in Lesotho - Department of NFE and the Lesotho Distance Teaching Centre. Additionally, Lesotho Association of Non-Forla Education and the Monna ka Khomo [man by cow] Herders Association also participated in this study. In acknowledgement that herders were also human beings with basic rights, the author gave the herders a choice to freely participate in the study willingly and ensured that their rights and welfare were protected by using anonymised names in the form of pseudonyms and confidentiality.

\section{Findings and discussions}

The findings revealed that herding was indeed resourceful in facilitating herders' acquisition of IK. It was further found that the interaction that the herders had among themselves, the elders and their herding environment enabled informal learning that was oral in nature and relevant to address the day-to-day challenges of herding life. For instance, the herders learned how to use the traditional herbs to mitigate both human and veterinary healthcare problems. The herders also discovered the IK technologies applicable for healing their livestock. The availability of local resources such as grass and wild animals also became a resource for teaching the herders arts and crafts, where they used both grass and wild animal skins to make sunhats and warm winter hats, respectively. While Nyiraruhimbi (2012) categorises IK into three groups - local science, local memory and local practicethis article will only concentrate on local science and local practice knowledge because they seemed to be common among the herders.

\section{Local science knowledge}

The local science findings revealed that Basotho herders used the traditional herbs found within the herding environment for both human primary healthcare as well as veterinary care. Others talked about how they learned about the indigenous technologies from herding. Most of the learning came through social interaction among herders or with their elders. In one of the stories it was indicated that some of the skills such as that of being a herbalist are learned from grandfathers:

'When I came to Maseru, I wanted to put my herbalist skills into practice in order to generate income for my family. I learned this skill from my grandfather who was a renowned traditional doctor in my community. I used to follow him around when he went out in the field to dig out the herbs. As time passed on, he became confident that I had learned enough to be able to carry out some simpler healing tasks for him. However, since I am not a spiritually called divine healer I do not consider myself competent enough to carry out complex tasks. Therefore, I want my clients to consult the traditional healers first for diagnosis and then come to me for treatment. I have all the different herbs to cure most diseases and problems'. (Doctor, 43 years old, male herder)

The preceding story reveals the important contribution that interaction makes in IK learning. For instance the doctor did benefit from the social interaction provided through the apprenticeship method (an approach whereby an apprentice is attached to a specialist mentor) of learning, under the watchful eye and mentorship of his grandfather. This story affirms the literature in Magni (2016), which underscores the resourcefulness of social interaction in providing learning support.

On the other hand, Alex (real name withheld), aged 28 years and a bachelor, mentioned how his knowledge of traditional herbs was an outcome of a peer-to-peer social interaction:

'Herding life taught me the different names of the various traditional herbs and the ailments that can be cured with such herbs. I also know how to dig and prepare these herbs before consumption; the knowledge which I have turned into an income-generation activity that targets the tourists. [He picked up a bundle.] This is a bunch of ralikokotoana or monna motšo translated as 'the black man', it grows amongst the cheche bushes. The useful part in this herb is the black bark [hence the name monna motšo], which is used for 'servicing' the body. It is tasteless and can either be chewed or boiled. When the bark is chewed, the herb serves as a mild purgative that deals with gall-bladder related problems as well as discharge. It also works very well when mixed with sehala hala sa matlaka. This one is called moli or African potato, which is effective for cleaning the blood as well as blood circulation. I have also recommended qobo to new mothers because of its healing properties, particularly for those women who have just delivered their babies'. (Alex, 28 years old, male herder)

In this story the acquired herding IK has been shared orally and informally beyond the herding fraternity. Much of the acquired knowledge included the names of the various traditional herbs, how those herbs were used and their remedial effects to different ailments. These findings affirm the oral and sharing nature of IK. The role of the peers in facilitating local science knowledge was echoed by Semonkong, who further elaborated on how he prepared the herbs before consumption as follows:

'In order to prepare the medication before boiling, I have to (tula) crush the herbs and then put them to boil for some time to 
be ready for drinking. Then I let them cool and pour into this container to be ready for sale. I sell them either in (lihlopha) bundles so that the customer can prepare the medicine at home or I sell them already boiled and ready for drinking, like what I have in this 5-litre container'. (Semonkong, 29 years old, male herder)

Semonkong identified the different methods that he used in the preparation of the various herbs. In his explanation he mentioned the drying, crushing, boiling and bundling of the herbs before consumption. In some stories, the herders explained the different methods through which they administered traditional herbs:

'When I feel dizzy or suffer from gall bladder-related ailments, I mix letapisa, hloenya and lengana to induce forced vomiting (ho $\left.k^{\prime} h a p h a\right)$. My parents taught me the effectiveness of this technique and I have been using it without fail from a very tender age because it has never failed me'. [Comrade, 30 years old, male herder]

On the other hand, the 24-year-old Taiwan introduced additional new methods that he used to administer the herbs as follows:

'In order for me to effectively manage flu-related symptoms, I usually mix phefo and bloukomo in hot water and steam my body (kea futha). When I have a headache, I crush poho tšehla into fine powder and then sniff that powder. The healing effects are always quick because the powder goes directly to the affected area through the nostrils. After a few sneezes, the headache is gone'. (Taiwan, 24 years old, male herder)

These herbs are also used to treat different illnesses that the livestock present with. Some of the knowledge has been acquired from other herders while the other is passed on to the herders by the elders. For instance, Linakaneng explained how he attends to his sick livestock:

'If the animal gets sick, I mix the following: mohalalitoe, makhona tsohle and salt and either give the mixture to the sheep, dry as it is (kea li komisa), or mix with water. The other common herbs, depending on the illness for the sheep, would be sehala hala sa matlaka and monatja'. (Linakaneng, 24 years old, male herder)

\section{Echoed by Comrade:}

'I also use some traditional herbs such as aloe, sulphur and blue stene to cure papisi on horses and use hloenya, mohalalitoe and mofifi to cure sheep'. (Comrade, 30 years old, male herder)

The findings regarding traditional herbs as local science revealed that the traditional herbs can effectively cure different ailments. It was also discovered that these herbs are prepared differently depending on the ailment that they are intended to cure (Moteetee \& Van Wyk 2011). Basotho herders also administer the traditional herbs differently based on the intended ailments that they are prepared to cure and the desirable herbal preparation for that particular ailment and herb used.

The use of local technologies as local science knowledge was also revealed, as well as the benefits in dealing with animal health-related issues. For instance, Makau (real name withheld) elaborates on how he acquired IK knowledge from his grandfather as follows:

'I grew up looking after my maternal grandfather's livestock and that is where he [grandfather] taught me how to treat a broken leg of a cow using the local technologies. For instance if the cow has broken a rear leg, I take some strong sticks and wrap them around the fractured area for support. I then tie those sticks around the leg using a thin rope and a cloth. The cow will not go out to the grazing area together with others. After sometime when it is able to walk with the broken leg, I loosen the ropes and remove the sticks leaving only the cloth and the rope so that the animal can be able to bend the tissues. Failure to do so on time results in a permanent paralysis because the tissues will be too stiff to bend'. (Makau, 36 years old, male herder)

This story traces the treatment of the broken leg from the onset of the treatment, and the care proceeds until the recovery phase of the animal. The story affirms the findings in recent studies (Johnson 2016; Ngozwana 2014), which agree that IK is passed on from older generations to younger ones using informal oral methods.

\section{Local practice}

The findings presented under this subtheme comprise a variety of creative arts and crafts skills that the herders developed over time while herding. In some cases the herders used animal skins of the very animals that they looked after. For instance, they used cattle and sheepskin to make blankets, sleeping mats, even leather shoes. They also decorated their only universal herder identity artefact (the grey blanket). Some hats were also made of mosea (a special grass that is commonly found in the highlands of Lesotho) to curb the devastating effects of the sun. The creative skin-crafting skills that the herders acquire through herding are revealed in the story narrated by the 24-year-old herder:

'Among the numerous skills that I acquired through herding is that of making leather shoes - qoatho. These are sandals made out of an animal skin such as goat, cow and a horse. Qoatho is a local name that we use for this shoe type in my community of Linakaneng... I also make skin ropes - marapo where I use softened cow or horse hide. These ropes are reliable because of their durability'. (Linakaneng, 24 years old, male herder)

Linakaneng's interests also extend into decorating the herders' grey blanket:

'I also decorate the grey blanket as it is one item that identifies Basotho herders. In order to do this I collect wool of different colours and then write different catchy English messages on the blanket using my Standard 2 class English (equivalence of Grade 2 in South Africa). This would include the totem, pictures of cars and big houses that I aspire to own in the future. Sometimes I draw my animals and guns because the high rate of livestock theft makes animals and guns inseparable'. (Linakaneng, 24 years old, male herder)

The story of Linakaneng reveals the potential opportunity that herding IK has as an income generation initiative, which herders explore as they benefit from the proceeds of their 
business. He further stated how his business has finally earned him respect from his community because he was economically empowered and able to support his povertystricken family. In his own words:

'Batho baea nthompha joale [people now respect me]. Whenever I go to the village, they always envy my financial achievement ...' (Linakaneng, 24 years old, male herder)

During the data collection, I had the honour of being invited into Linakaneng's cattle post house, where he revealed how he had transformed the bottom of a 5-litre container into a mini-washing basin just big enough to allow him to wash his face and to wash one foot at a time in order for him to look presentable when he went home for a visit or to replenish his supplies. Stories such as this one indicate how herding limits the herders' access to social services. The story also reveals the important role played by the herding environment as a learning resource for herders. Their isolation and remoteness sparks creative ways of thinking and doing in order for them to cope with herding. This story also affirms the arguments presented in Odora Hoppers (2017b) in that knowledge production has to take into consideration the prior knowledge in order to build on the newly acquired knowledge and skills. In this story, Linakaneng's basic hygiene knowledge urged him to improvise in cases of lack of the necessary amenities that he needed in order to keep himself clean. Similarly, Odora Hoppers (2017b) opines that knowledge has to be constructed using methods that allow for a reflexive stance that would move research out of the academic confinement into real-time application in order to facilitate change. In this article, the undocumented herding IK is collected and presented as a record, which other researchers with similar interests can access and customise to their contexts. Most importantly is the applicability of these findings in facilitating change in the current NFE policy and practice in Lesotho.

In another story, the 43-year-old Doctor, who had turned his herding IK into a family business, outlined how he learned to make the traditional grass sunhats following a disappointment that he experienced from his supplier that nearly cost him his business. He elaborates:

'One day my regular supplier disappointed me so much that I nearly lost my business and the good rapport that I have built over time with my customers. We had agreed that he would deliver a large quantity of grass sunhats, which had been ordered for collection in Johannesburg. Unfortunately my supplier failed to deliver the commodity on time and I got very upset. The following morning I decided that I was going to learn how to make my own hats. It was not easy at first but I recalled the skills that I acquired from my herding experience and put them to good use. While my order was delayed because of the hiccup, I was able to complete the required quantity and supplied my customer'. (Doctor, 43 years old, male herder)

Doctor not only learned how to make grass sunhats from herding, but he was also among the best suppliers of animal skin hats. He explained:

'My herding experience also taught me how to knit hats using wild animal skins for myself in order to keep warm during the cold winter season. Through that experience, I make and sell the best animal skin hats here. Mine are different and stand out from those of other dealers, because I work the skin to make it softer before knitting. Additionally, I work together with my daughter to line the hats in such a way that they are not only easy to wear but they also feel comfortable. I mainly use the skin from a male jackal because of the beauty of the skin, in the absence of which I use that of a wild cat. My customers are mainly men, especially those who have a substantial experience in cattle post herding in that the hats constantly remind them of their past ...' (Doctor, 43 years old, male herder)

While naturally Doctor would be in despair because of the non-delivery of his goods, in his case he transformed his behaviour from the complacency stage into that of accountability and learning to be in charge of his business interests. Instead of buying the hats he changed his behaviour and made his own hats. The story not only reveals the multitalent empowerment ability that comes with herding but it also highlights the holistic nature of IK. For instance, the teaching and learning practice is intertwined within the daily routine of the herders in order to help them to apply the knowledge and skills that they acquire in real life (Pitikoe 2017; Pitikoe \& Morojele 2017; Pitikoe \& Preece 2016). The story further indicates how IK is passed on from the older generation to the younger ones. This is evidenced in the way the Doctor and his daughter work together in the refinement of their product for the common economic good of all - in this case, Doctor's family. Equally important, the oral and informal nature of IK becomes clear (Johnson 2016; Ngozwana 2014).

Livestock herding not only teaches the herders about arts and crafts, but it also teaches them self-defence skills through indigenous games in preparation for their future social roles as protectors for both their families and communities. This practice is elaborated in Taiwan's story. The 24-year-old bachelor from Qacha's Nek District explains how they learn through games while herding:

'Herding is indeed lonely but there are other things that we do as herders during the day. For instance we play traditional games such as morabaraba [a board game that is similar to chess]; ho kalla [mock stick fights] and ho khoasa litali [rat hunting]. We also sing to prepare for the community held concerts so that we can meet with the girls and express our love intentions to them'. (Taiwan, 24 years old, male herder)

In other words, acquisition of herding IK comes in different forms, which include extramural activities such as games and music. What is also important in this story is the contribution that social integration and collaboration play in facilitating learning and a sense of belonging.

\section{Discussion}

It was discovered that Basotho herders mainly acquired their IK orally and informally (Johnson 2016; Ngozwana 2014; Pitikoe 2017; Pitikoe \& Morojele 2017). Herders 'interaction with the environment, their peers and the elders had significantly contributed to the herders' teaching and 
learning practice (Pitikoe 2017; Pitikoe \& Morojele 2017). It was also found that the herders possessed two categories of valuable IK skills in the form of local science and local practice (Pitikoe 2017; Pitikoe \& Preece 2016).

Literature on herding in Lesotho's context is quite scarce and the available studies are descriptive in nature (Makoa \& Zwilling 2005; Nthunya 1996). What is lacking in these studies, though, is the theoretical perspective, which this article seeks to address. The literature identified some gaps in Lesotho's policy environment (Morojele 2009). For instance, the delayed implementation of the Lesotho Education Act of 2010 as an education enforcement mechanism has left room for parents and livestock owners to prioritise herding over schooling. While Osborne et al. (2015) identifies the potential contribution that IK can make in teaching and learning policy and practice, Lesotho has not made a very strong commitment in this field of research. Nonetheless, their high level of innovation further affirmed the subjective nature of knowledge construction - there is no absolute truth; rather, truth is factual and based on values. The wisdom that comes with herding helps the herders in the management of the uncertainties that come with herding responsibilities (Ratau 1988). This innovation can potentially be a resource to tap in developing an education programme that addresses the herding communities, in that it can inform appropriate teaching and learning methods that can adequately address the herders' learning needs.

While the findings reveal the herders' willingness to learn, and the important role played by social interaction as a learning resource, the high rates of males dropping out of formal schooling in order to join the herding community are alarming, given the global outcry for the universal education provision (Pitikoe 2017; Pitikoe \& Morojele 2017). Therefore, NFE becomes a better positioned provision that can cater for the herders' education needs (Pitikoe 2016). However, the provision lacks political and financial support from the government, which has resulted in Lesotho's NGOs taking over the implementation process under donor support (Pitikoe 2017). Unfortunately, the donor funds come with donor-driven expectations on how the funds should be disbursed. Most of these expectations are exotic and do not meet the local education needs. Given the oral nature of IK and the limited research, not much is known on how Lesotho can integrate IK into the education system. The findings from this article will shed some light to the decision-makers on the things that the herders already know that could be integrated into the current provision in such a way that it becomes attractive to the herders.

The author acknowledges the significant contribution that the study has made in establishing a deeper understanding of the herding practice in Lesotho and how the herders acquired IK and used it in the herding fraternity. However, this is not enough. This study may become a catalyst for a more detailed investigation on Lesotho's herding practice that would involve other methods of data collection, including participant observation. While it was anticipated that this study would establish a deeper understanding of how herders learned, the methods did not dig deeply enough because of a lack of funding, which affected the initial data collection plan. For instance, the herders did not have enough time to think over and decide on the types of pictures that they had to take in order to communicate their inner feelings about herding.

\section{Conclusion}

This article looks at the complexity through which Basotho males acquire IK through their routine herding practice. The key findings from this study revealed that herding is a maledominated practice that males assume at a very tender age from as young as 3 years in Lesotho. While the literature categorises IK into local science, local practice and local memory (Nyiraruhimbi 2012), Basotho herders mostly acquired local science and local practice knowledge. The local science knowledge included different traditional herbs, which the herders used to treat minor human and livestock ailments. It was also discovered that the herbs were prepared and administered through different methods. The local science knowledge also included local technologies that the herders used to treat animal fractures. Similarly, the findings regarding the local practice revealed a wealth of knowledge that the herders possessed in arts and crafts. This included hat-making using animal skins and grass, leather sandals and decoration of the grey blanket. Much of the learning was oral, generational and informal, and social interaction played a significant role as a learning resource. Therefore, the article suggests the following:

- The article found that local science knowledge comes with a wealth of undocumented local technologies that are known only to herders. Therefore, more IK research is needed that would inform Lesotho's way forward on how to integrate IK in Lesotho's NFE policy and practice.

- While poverty is identified as one of the education impediments, herding comes with IK skills that herders use to generate income under both local science and local practice. Such initiatives can be harvested, documented and included in the education programmes that target Basotho herders.

- While evidence shows a high influx of Basotho males into the herding fraternity, there is a paucity of literature on the drivers of this influx. The article suggests a need for further research to establish a deeper understanding of the factors that attract Basotho males to herding practice, which may be lacking in education provision.

\section{Acknowledgements}

This article owes its success to the University of KwaZuluNatal, which committed funds in support of the final publication of the article. The author also wishes to acknowledge the mentorship, guidance and support provided by Professors Preece and Morojele of the University 
of KwaZulu-Natal Adult Education Department and College of Research, respectively. The author also extends her sincere acknowledgements to Basotho herders who committed time out of their busy herding schedules; the NFE coordinator, the staff from Lesotho Distance Teaching Centre, Lesotho Association of Non-formal Education and Monna ka Khomo Herdboys Association for their contribution in the data collection process.

\section{Competing interests}

The author declares that there were no financial or personal relationships which may have inappropriately influenced the writing of this article.

\section{References}

Arthur, J., Waring, M., Coe, R. \& Hedges, L., 2012, Research methods and methodologies in education, Sage publications, London.

Baloyi, M.E., 2014, 'Distance no impediment for funerals: Death as a uniting ritual for African people - A pastoral study', Verbum et Ecclesia 35(1), 1-7. https://doi. African people - A pastoral
org/10.4102/ve.v35i1.1248

Chilisa, B. \& Preece, J., 2005, Research methods for adult educators in Africa, Pearson Education South Africa and UNESCO, Cape Town.

Choabi, T.E., 2016, Pastoral approach to the African Christian woman affected by grief due to the loss of her spouse, University of North-West, Mafikeng.

Ekaju, J., 2011, 'An investigation into the relationship between the 1997 universal primary education (UPE) policy and regional poverty and educational inequalities in Uganda (1997-2007)', A thesis submitted in partial fulfilment of the degree of Doctoral of Education, Humanities, University of Glasgow, Glasgow.

Frąckowiak, A., 2017, 'A review of lifelong learning as natural and cultural phenomenon', International Journal of Psycho-Educational Sciences 6(2), 1-11.

Gill, S.J., 1993, A short history of Lesotho, Morija Museum and Archives, Morija.

Government of Lesotho (GOL), 2015, Lesotho national human development report: Leveraging the power of youth to promote human development, United Nation Development Programme, New York.

Johnson, L.R., 2016, 'Cultural and social uses of orality and functional literacy: A narrative approach', Reading \& Writing 7(1), 1-7. https://doi.org/10.4102/rw. v7i1.119

Lefoka, J., 2007, 'Out of School Missing Boys-a Study from Lesotho', Commonwealth Education Partnerships. Retrieved from http://www.ungei.org/resources/files/ Lesotho.pdf

Letsosa, R. \& Semenya, K., 2011, 'A pastoral investigation of the phrase "go tloša Setšhila" [traditional purification] as the last phase in the process of bereavement
mourning amongst the Basotho', Verbum et Ecclesia 32(1), 1-7. https://doi. mourning amongst the Baso
org/10.4102/ve.v32i1.489

Magni, G., 2016, Background paper prepared for the 2016 global education monitoring report education for people and planet: Creating sustainable futures for all. Indigenous knowledge and implications for the sustainable development agenda, Indigenous knowledge
UNESCO, Hamburg.

Makoa, T. \& Zwilling, A., 2005, Shepherd boy of the Maloti, Morija Museum and Archives, Morija.

Maloka, T., 1988, 'Basotho and the experience of death, dying, and mourning in the South African mine compounds, 1890-1940', Cahiers d'études Africaines 38(149), 17-40. https://doi.org/10.3406/cea.1998.1975

Matope, T., 2011, 'Battling an age old tradition and custom: Monna ka Khomo Herdboys association seeks to ensure parents look beyond the herding of livestock for their children', Public Eye Friday, 15 April, Public Eye Newspaper, pp 1-22, Maseru.

Matšela, Z.A., 1979, 'The indigenous education of the Basotho and its implications for educational development in Lesotho', Unpublished PhD thesis, A thesis submitted in partial fulfilment of the degree of Doctoral of Education, Humanities, University of Massachusetts, Amherst, Massachusetts.

Ministry of Education and Training (MoET), 2001a, Unpublished non-formal education in Lesotho. Draft policy document, Lesotho Government Printing, Maseru.
Ministry of Education and Training (MoET), 2001b, Free primary education programme, Watermark, Pretoria.

Ministry of Education and Training (MoET), 2005, Unpublished Lesotho education sector strategic plan 2005-2015, Lesotho Government Printing, Maseru.

MoHSW, 2009, Lesotho demographic and health survey, Ministry of Health and Social Welfare, Maseru.

Morojele, P., 2009, 'Construction of gender in the context of free primary education: A multi-site case study of three schools in Lesotho', A thesis submitted in partial fulfilment of the degree of Doctoral of Education, Humanities, University of KwaZulu-Natal.

Moteetee, A. \& Van Wyk, B.E., 2011, 'The medical ethnobotany of Lesotho: A review', Bothalia 41(1), 209-228. https://doi.org/10.4102/abc.v41i1.52

Ngozwana, N., 2014, 'Understandings of democracy and citizenship in Lesotho: Implications for civic education', A thesis submitted in partial fulfilment of the degree of Doctoral of Education, Humanities, University of KwaZulu-Natal.

Nthunya, M., 1996, Singing away the hunger: Stories of a life in Lesotho, University of Natal Press, Pietermaritzburg.

Nyiraruhimbi, A., 2012, 'Indigenous approaches to maize production and soil management in Msinga, Kwazulu Natal Province', A dissertation submitted in management in Msinga, Kwazulu Natal Province', A dissertation submitted in
partial fulfilment of the degree of Master of Agriculture, Humanities, University of partial fulfilment
KwaZulu-Natal.

Odora Hoppers, C., 2017a, Culture, indigenous knowledge and development: The role of the University, Center for Education Policy Development Systems, role of the Uning
Braamfontein.

Odora Hoppers, C., 2017b. 'Transformation and change in knowledge generation paradigms in the African and contexts: Implications for education research in the 21st Century', Educational Research for Social Change 6(1), 1-11. https://doi. 21st Century', Educational Research for
org/10.17159/2221-4070/2017/v6i1a1

Opong, A.K., 1997, The religious significance of ritual practices conducted at births, weddings and funerals in Lesotho, University of South Africa, Pretoria.

Opong, A.K., 2004, 'Some religious aspects of Basotho funeral rituals', Journal for the Study of Religion 17(2), 25-45.

Osborne, D., Cutter, A. \& Ullah, F., 2015, Universal sustainable development goals: Understanding the transformational challenge for developed countries, viewed 01 July 2014, from www.stakeholderforum.org

Pitikoe, S., 2016, 'Male herders in Lesotho: Life history, identities and educational ambitions', A thesis submitted in partial fulfilment of the degree of Doctoral of Education, Humanities, University of KwaZulu-Natal.

Pitikoe, S., 2017, 'Basotho herders learn through culture and social interaction', Learning, Culture and Social Interaction 13, 104-112. https://doi.org/10.1016/j. Icsi.2017.03.003

Pitikoe, S. \& Morojele, P., 2017, 'Indigenous knowledge/s of survival: Implications for lifelong learning among the Basotho herding fraternity', Educational Research for Social Change (ERSC) 6(1), Special Issue, 38-55.

Pitikoe, S. \& Preece, J., 2016, 'Herder identity in Lesotho: Implications for non-formal education', International Journal of Lifelong Education 35(6), 607-628. https:// doi.org/10.1080/02601370.2016.1203831

Pitikoe, S. \& Preece, J., 2017, 'The public image of the herders in Lesotho and implication for the non-formal education curriculum', African Identities 15(4), 457-471. https://doi.org/10.1080/14725843.2017.1319757

Preece, J. 2013, 'Service learning and community engagement in South African Universities: Towards an adaptive engagement approach', Alternation Special Edition 9, 265-291.

Rakotsoane, F.C.L. \& Rakotsoane, M.A., 2007, The ABC of research project, dissertation and thesis proposal writing, rev edn., Choice Publishing Company, Maseru.

Ratau, J., 1988, Molisana oa Mosotho, Morija Printing and Archives, Morija.

Shar, M.K., Kambou, S.D. \& Monahan, B., 1999, Embrasing participation in development: Worldwide experience from CARE's reproductive health programs with a step-by- step field guide to participatory tools and techniques, CARE, Atlanta.

UNDP, 2012, Africa human development report: Towards a food secure future, United Nations Development Programme, New York.

Webb, P., 2017, 'Africanizing educational research and practice', Educational Research for Social Change 6(1), vii-viii.

Williams, R.L. \& Metz, A.E., 2014, 'Examining the meaning of training animals: A photovoice study with at-risk youth', Occupational Therapy in Mental Health 30(4), 337-357. https://doi.org/10.1080/0164212X.2014.938563

World Bank, 1998, Indigenous knowledge for development: A framework for action, Knowledge and Learning Center Africa Region World Bank, Washington, DC. 